CZASOPISMO INŻYNIERII LĄDOWEJ, ŚRODOWISKA I ARCHITEKTURY JOURNAL OF CIVIL ENGINEERING, ENVIRONMENT AND ARCHITECTURE

JCEEA, t. XXXIII, z. 63 (3/16), lipiec-wrzesień 2016, s. 287-294

\author{
Vlasta ONDREJKA HARBULAKOVA ${ }^{1}$ \\ Pavol PURCZ ${ }^{2}$ \\ Adriana ESTOKOVA ${ }^{3}$ \\ Alena LUPTAKOVA ${ }^{4}$
}

\title{
RELATION BETWEEN CONCRETE LEACHABILITY AND pH USING STATISTICAL APPROACH
}

\begin{abstract}
Attack of external water to concrete results in the degradation of cement and changes the concrete pore water and solid phase composition. The leaching behaviour of cement-based products have been shown to be similar after assessing the leaching characteristics by means of a $\mathrm{pH}$ dependence leaching test. The paper is focused on the investigation of the leachability of the concrete samples of different composition due to distilled water and its relation to $\mathrm{pH}$. Si, $\mathrm{Ca}, \mathrm{Al}, \mathrm{Fe}$ and $\mathrm{Mn}$ ions leached out from the cement matrix were measured after each of fives experimental cycles. Three sets of samples were studied: without fly ash, and containing coal fly as cement replacement (5 wt. \% and 10\% wt. respectively). Statistical methods were used for the intensity and course of deterioration assessment regarding a dependency of $\mathrm{Si} / \mathrm{pH}, \mathrm{Ca} / \mathrm{pH} \mathrm{Al} / \mathrm{pH}$ and $\mathrm{Fe} / \mathrm{pH}$ and $\mathrm{Mn} / \mathrm{pH}$ for each type of samples. The correlation among leaching processes according to type of concrete were also statistically studied.
\end{abstract}

Keywords: correlation coefficient, distilled water, calcium, silicon

\section{Introduction}

Deterioration due to leaching occurs gradually in structures in long-term contact with water. Leaching is a diffusion-reaction phenomenon which takes place significantly when concrete is exposed to poorly mineralized or acid water.

${ }^{1}$ Corresponding author / autor do korespondencji: Vlasta Ondrejka Harbulakova, Technical University of Kosice, Faculty of Civil Engineering, Institute of Environmental Engineering, Vysokoskolska 4, 04200 Kosice, Slovakia, +421 55602 4269, vlasta.harbulakova@tuke.sk

2 Pavol Purcz, Technical University of Kosice, Faculty of Civil Engineering, Department of Applied Mathematics, +421 55602 4269, pavol.purcz@tuke.sk

3 Adriana Estokova, Technical University of Kosice, Faculty of Civil Engineering, Institute of Environmental Engineering, Vysokoskolska 4, 04200 Kosice, Slovakia, +421 556024265 , adriana.estokova@tuke.sk

${ }^{4}$ Alena Luptakova, Slovak Academy of Science, Institute of Geotechnics, Watsonova 45, 04353 Kosice, Slovakia, +421 557922 622, luptakal@saske.sk 
This results in the elusion of major components of concrete, and is called corrosion by leaching [1]. Degradation consists in dissolution of calcium and hydroxide ions out of the matrix, which causes an increase in porosity and transport properties of surface concrete [2,3]. Leaching is accelerated in neutral and acid solutions $[4,5]$, and it may be coupled with the ingress of aggressive ions such as chloride, sulphate, magnesium [6,7]. As the Calcium (Ca) hydrate in concrete dissolves and migrates into water around the concrete structure, the concrete becomes porous. This type of deterioration is known as "concrete deterioration caused by $\mathrm{Ca}$ leaching", it progresses very slowly compared to other deteriorations such as the alkali-aggregate reaction or chloride attack. Consequently, this deterioration has not generally been considered in the design of ordinary concrete structure. However, in the design of special concrete structure with their service life over a hundred years or more, this type of deterioration must be considered [8].

A common indication of the tendency of a particular water to dissolve or precipitate calcium carbonate is content of the water, $\mathrm{pH}$ total alkalinity dissolved solids and temperature. Hard water (water containing dissolved calcium, magnesium and iron slats) will not dissolve calcium hydroxide to any appreciable extent, but soft water relatively free of the dissolved salts readily dissolves calcium hydroxide and may become quickly saturated with calcium [9]. The effects of other dissolved salts in water are major factor governing the dissolution of lime in concrete by water. Concrete exposed to water is not only subject to leaching but the deposition of mineral deposits as well. Mineral deposits may form on exposed surfaces where water seeps through concrete along joints and cracks of concrete structures, such as dam faces, pipeline and tunnels, retaining walls and abutments, and buildings foundations. Occasionally, surface evaporation leads to transport of water containing various ions through permeable concrete, resulting in deposition of salts on horizontal slabs or stem walls close to the soil line. Modern concrete often includes the use of supplementary cementitious materials. These materials are often co-products of other processes or natural materials. Some require further processing before they are suitable for concrete. Some of these materials have cementitious properties when used alone; others, called pozzolans, do no [10]. Fly ash, ground granulated blast-furnace slag, silica fume, and natural pozzolans, such as calcined shale, calcined clay or metakaolin, are materials that when used in conjunction with Portland or blended cement, contribute to the properties of the hardened concrete through hydraulic or pozzolanic activity or both. Fly ash is primarily silicate glass containing silica, alumina, iron, and calcium. Minor constituents are magnesium, sulphur, sodium, potassium, and carbon. Crystalline compounds are present in small amounts. The relative density (specific gravity) of fly ash generally ranges between 1.9 and 2.8 and the colour is generally grey or tans [11]. The chemical corrosion of concrete with fly ash in various aggressive environments was investigated and is presented in our previous papers [12, 13, 14]. 
The objective of this paper was to apply a statistical method to evaluate the results obtained in the experiments of chemical corrosion simulation. The paper presents a study of deterioration rate and course regarding a dependency of $\mathrm{Si} / \mathrm{pH}, \mathrm{Ca} / \mathrm{pH} \mathrm{Al} / \mathrm{pH}$ and $\mathrm{Fe} / \mathrm{pH}$ and $\mathrm{Mn} / \mathrm{pH}$ for concrete samples, with and without fly ash addition, using a correlation analysis. The correlations among leaching processes according to type of concrete were also statistically studied.

\section{Material and Methods}

Three types of concrete samples were used for the experiments simulating the chemical corrosion of concrete. First set of samples consisted of a concrete mixture according to a classic recipe without fly ash (marked as FA0), the second set of samples, marked as FA5, consisted of a mixture where $5 \mathrm{wt}$. \% of cement was replaced by coal fly ash and third set of samples, marked as FA10, contained $10 \mathrm{wt}$. \% of coal fly ash as cement replacement. The used coal fly ash with volumetric weight of $2381 \mathrm{~kg} / \mathrm{m}^{3}$ originated from black coal's burning process and was incorporated into cement composites without any modification. Concrete cylinder samples of a $32 \mathrm{~mm}$ diameter and $15 \mathrm{~mm}$ height were formed as a drilled core from concrete cube $(150 \times 150 \times 150 \mathrm{~mm})$, prepared according to a standard process, using drilling mechanism STAM. The cylinder concrete specimens were rid of impurity, dried and weighted, and exposed to a leaching medium represented by distilled water with a $\mathrm{pH}$ value of 6.25 .

Chemical corrosion-simulating-experiments proceeded in five consecutive cycles. Each cycle consists of the following steps: a seven-day exposition of sample to a liquid medium, a removal the sample from the liquid, a two-day drying of samples at room temperature and afterwards a removing of precipitations by little brush, a re-immersion of sample into the medium and finally adjustment of the $\mathrm{pH}$ value back to the initial value. The values of leachate's $\mathrm{pH}$ were measured by $\mathrm{pH}$ meter PHH - 3X Omega. Concentrations of elementary ions in leachates after each experimental cycle were determined using X-ray fluorescence analysis (XRF). The measured concentrations of dissolved ions, given in Table 1, and the $\mathrm{pH}$ values measured in leachates (Table 2) were used for the statistical investigation.

In statistics, dependence refers to any statistical relationship between two random variables or two sets of data. Correlation refers to any of a broad class of statistical relationships involving dependence. Methodology of correlation coefficient $\left(R_{\mathrm{xy}}\right)$ calculation was presented in our previous works [14] as well as in well-known statistical literature sources e.g Kreyszig, E. [15], Dodge, Y. [16].

Information about 2-dimensional statistical data set gives correlation coefficient $R_{\mathrm{xy}}$. Its values are from the interval $<-1,1>$. If $R_{\mathrm{xy}}=1$, the correlation is full linear, if $R_{\mathrm{xy}}=-1$, then the correlation is inversely linear and if $R_{\mathrm{xy}}=0$, the pairs of values are fully independent. Than degree of the correlative closeness is: medium, if $0.3 \leq\left|R_{\mathrm{xy}}\right|<0.5$; significant, if $0.5 \leq\left|R_{\mathrm{xy}}\right|<0.7$; high, if $0.7 \leq\left|R_{\mathrm{xy}}\right|$ $<0.9$; and very high, if $0.9 \leq\left|R_{\mathrm{xy}}\right|$. 
Table 1. Concentrations of studied elements dissolved in distilled water

Tabela 1. Stężenia badanych pierwiastków rozpuszczonych w destylowanej wodzie

\begin{tabular}{clcccccc} 
& & initial & $\begin{array}{c}\text { after } \\
\text { cycle 1 }\end{array}$ & $\begin{array}{c}\text { after } \\
\text { cycle 2 }\end{array}$ & $\begin{array}{c}\text { after } \\
\text { cycle 3 }\end{array}$ & $\begin{array}{c}\text { after } \\
\text { cycle 4 }\end{array}$ & $\begin{array}{c}\text { after } \\
\text { cycle 5 }\end{array}$ \\
\cline { 2 - 8 } FA0 & ions & & \multicolumn{5}{c}{ Concentration mg/L } \\
& $\mathrm{Ca}$ & 55.6 & 52.1 & 134 & 104.5 & 262.1 & 197.5 \\
& $\mathrm{Si}$ & 0 & 164.2 & 398.8 & 291 & 575.8 & 466.8 \\
& $\mathrm{Al}$ & 79.4 & 41 & 166.4 & 124.3 & 241.6 & 368.6 \\
& $\mathrm{Fe}$ & 0 & 0 & 4.3 & 0 & 7.5 & 7.3 \\
& $\mathrm{Mn}$ & 36.6 & 31.1 & 29.1 & 30 & 32.1 & 39 \\
\hline \multirow{5}{*}{ FA5 } & $\mathrm{Ca}$ & 55.6 & 45.2 & 197.8 & 88.5 & 256.9 & 90.6 \\
& $\mathrm{Si}$ & 0 & 119.3 & 439.8 & 283.6 & 521.2 & 378.8 \\
& $\mathrm{Al}$ & 79.4 & 28.5 & 169.2 & 107.9 & 216.1 & 166.1 \\
& $\mathrm{Fe}$ & 0 & 0 & 5.5 & 0 & 4.8 & 4.9 \\
& $\mathrm{Mn}$ & 36.6 & 47.2 & 25.4 & 21.8 & 25.9 & 29.6 \\
\hline \multirow{5}{*}{ FA10 } & $\mathrm{Ca}$ & 55.6 & 74.6 & 137.1 & 124.5 & 270.4 & 98 \\
& $\mathrm{Si}$ & 0 & 178.8 & 475.5 & 339.4 & 602.5 & 475 \\
& $\mathrm{Al}$ & 79.4 & 56.8 & 193.9 & 156.7 & 225.6 & 214.9 \\
& $\mathrm{Fe}$ & 0 & 0 & 0 & 0 & 1.8 & 4.6 \\
& $\mathrm{Mn}$ & 36.6 & 38.3 & 41.1 & 35.4 & 23.1 & 48.4
\end{tabular}

Table 2. $\mathrm{pH}$ values of distilled water before experiment and after each one of 7-days cycle

Tabela 2. Wartości pH wody destylowanej przed eksperymentem i po każdym z 7-dniowym cyklu

\begin{tabular}{cccccccc} 
& samples & initial & $\begin{array}{c}\text { after } \\
\text { cycle 1 }\end{array}$ & $\begin{array}{c}\text { after } \\
\text { cycle 2 }\end{array}$ & $\begin{array}{c}\text { after } \\
\text { cycle 3 }\end{array}$ & $\begin{array}{c}\text { after } \\
\text { cycle 4 }\end{array}$ & $\begin{array}{c}\text { after } \\
\text { cycle 5 }\end{array}$ \\
\cline { 2 - 8 } pH & FA0 & 6.25 & 8.36 & 8.4 & 8.56 & 8.22 & 8.11 \\
& FA5 & 6.25 & 8.01 & 8.27 & 8.49 & 8.24 & 8.12 \\
& FA10 & 6.25 & 7.88 & 8.41 & 8.56 & 8.32 & 8.24
\end{tabular}

A statistic approach was used for an evaluation of leachability of concrete's basic elements depending on the leachates' $\mathrm{pH}$ and for a comparison of dissolving the selected ions ( $\mathrm{Ca}, \mathrm{Si}, \mathrm{Fe}, \mathrm{Al}$ and $\mathrm{Mn}$ ) regarding the type of concrete sample.

\section{Results and Discussion}

The results of the correlation analysis of chemical elements concentrations in leachates and $\mathrm{pH}$ values considering different types of concrete samples are presented in Table 3.

As seen in Table 3, the highest correlation was found for the dissolved concentrations of silicon and $\mathrm{pH}$ value of the leachant $(0.65,0.75$ and 0.82 for the samples without fly ash, with $5 \mathrm{wt}$ \% of fly ash, and with $10 \mathrm{wt} . \%$ of fly ash, respectively). The correlations between the leached out concentrations and leachate's $\mathrm{pH}$ for the other ions were less significant. When compared the corre- 
Table 3. Correlation coefficients for a dependence Chemical element - $\mathrm{pH}$

Tabela 3. Współczynniki korelacji dla pierwiastków chemicznych - pH

\begin{tabular}{cccc} 
& \multicolumn{3}{c}{$R_{\mathrm{xy}}$} \\
\cline { 2 - 4 } & FA0 & FA5 & FA10 \\
\hline $\mathrm{Ca}-\mathrm{pH}$ & 0.35 & 0.42 & 0.52 \\
$\mathrm{Si}-\mathrm{pH}$ & 0.65 & 0.75 & 0.82 \\
$\mathrm{Fe}-\mathrm{pH}$ & 0.28 & 0.42 & 0.25 \\
$\mathrm{Al}-\mathrm{pH}$ & 0.23 & 0.39 & 0.64 \\
$\mathrm{Mn}-\mathrm{pH}$ & -0.57 & -0.44 & -0.01
\end{tabular}

lation coefficients regarding the type of concrete sample, the lowest correlation was observed for the concrete samples without fly ash (FA0) while the highest ones for the concrete samples with $10 \mathrm{wt} \%$ of fly ash (FA10). This finding was not true for the dependencies Fe-pH and Mn-pH. There was even found absolutely no Mn-pH correlation $\left(R_{\mathrm{xy}}=0.01\right)$ for the sample with $10 \mathrm{wt}$. \% of fly ash.

The dependencies between leachability of particular ions from the concrete samples, containing different content of fly ash, were also studied. The calculated correlation coefficients for calcium, silicon, iron, aluminium and manganese are shown in Table 4.

Table 4. Correlation coefficient of dissolved chemical element(s) according to percentage of fly ash replacement (X0 - no fly ash; X5 $=5 \mathrm{wt} . \%$ of fly ash; X10 = 10wt.\% of fly ash)

Tabela 4. Współczynnik korelacji rozpuszczonych pierwiastków chemicznych według procentu zastąpienia lotnego popiołu (X0 - brak popiołu; X5 $=5 \%$ wag. popiołu; $\mathrm{X} 10=10 \%$ wag. popiołu lotnego)

\begin{tabular}{clc} 
& & $R_{\mathrm{xy}}$ \\
\cline { 2 - 3 } $\mathrm{c}(\mathrm{Ca})$ & $\mathrm{Ca}_{0}-\mathrm{Ca}_{5}$ & 0.79 \\
& $\mathrm{Ca}_{0}-\mathrm{Ca}_{10}$ & 0.84 \\
& $\mathrm{Ca}_{5}-\mathrm{Ca}_{10}$ & 0.91 \\
\hline \multirow{3}{*}{$\mathrm{c}(\mathrm{Si})$} & $\mathrm{Si}_{0}-\mathrm{Si}_{5}$ & 0.98 \\
& $\mathrm{Si}_{0}-\mathrm{Si}_{10}$ & 0.99 \\
& $\mathrm{Si}_{5}-\mathrm{Si}_{10}$ & 0.99 \\
\hline \multirow{3}{*}{$\mathrm{c}(\mathrm{Fe})$} & $\mathrm{Fe}_{0}-\mathrm{Fe}_{5}$ & 0.92 \\
& $\mathrm{Fe}_{0}-\mathrm{Fe}_{10}$ & 0.78 \\
& $\mathrm{Fe}_{5}-\mathrm{Fe}_{10}$ & 0.58 \\
\hline \multirow{2}{*}{$\mathrm{c}(\mathrm{Al})$} & $\mathrm{Al}_{0}-\mathrm{Al}_{5}$ & 0.78 \\
& $\mathrm{Al}_{0}-\mathrm{Al}_{10}$ & 0.85 \\
& $\mathrm{Al}_{5}-\mathrm{Al}_{10}$ & 0.96 \\
\hline \multirow{3}{*}{$\mathrm{c}(\mathrm{Mn})$} & $\mathrm{Mn}_{0}-\mathrm{Mn}_{5}$ & -0.19 \\
& $\mathrm{Mn}_{0}-\mathrm{Mn}_{10}$ & -0.40 \\
& $\mathrm{Mn}_{5}-\mathrm{Mn}_{10}$ & -0.17
\end{tabular}


Table 4 shows a very high correlation $\left(\left|R_{\mathrm{xy}}\right| \geq 0.9\right)$ between the dissolved silicon concentrations from all 3 types of concrete samples during the experimental cycles. This finding points to the similar leaching mechanism of silicon ions regardless the composition of concrete. Taking into account the high correlation Si-pH mentioned above (Table 3), we can conclude that the silicon hydroxide is the main form of silicon leached out not only from the samples based on the ordinary Portland cement but from the samples containing the fly ash as well.

Similarly, a very high correlation $\left(\left|R_{\mathrm{xy}}\right| \geq 0.9\right)$ was observed for aluminium and calcium leaching, respectively, considering samples FA5 and FA10 while a lower correlation was found for aluminum and calcium leachability considering samples FA0 - FA10, and FA0 - FA5. The results indicate a quite different leachability of both aluminum and calcium regarding the concrete composition.

As it is shown in Figure 1, there is an inverse proportionality for leachability of manganese ions. However, almost no correlation was found $\left(\left|R_{\mathrm{xy}}\right|=0.17\right.$, 0.19 and 0.4 ) when comparing the dissolved concentrations from the various concrete samples during the experiment.

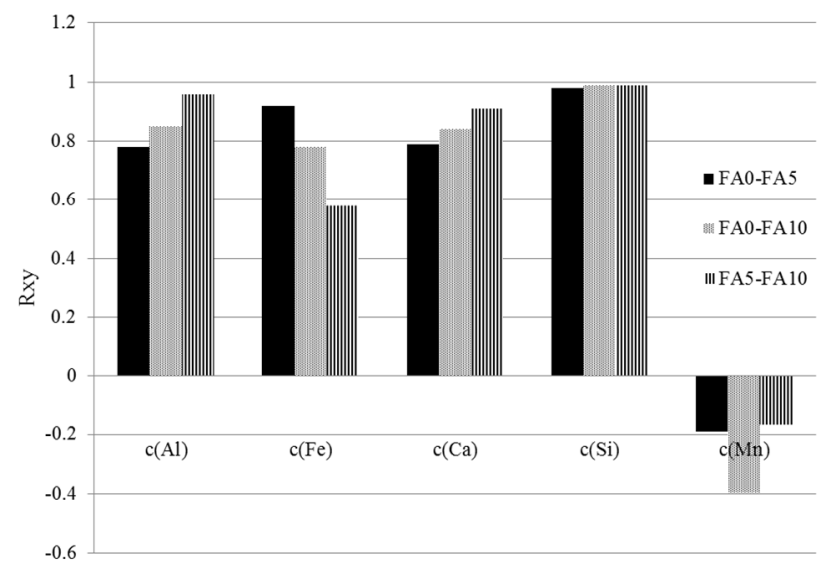

Fig. 1. Correlation coefficients for a dependence between dissolved ions concentrations from concrete samples considering various fly ash content

Rys. 1. Współczynniki korelacji między stężeniami rozpuszczonych jonów $\mathrm{z}$ próbek betonowych $\mathrm{z}$ uwzględnieniem różnej zawartości popiołu lotnego

High correlation was calculated for iron leaching (FA0-FA10). Same conclusion should be presumable calcium (correlation = high) and silicon (correlation $=$ very high) for all pairs of samples. The lowest dependency (significant) was measured in case of samples FA5-FA10 for leaching of iron. 


\section{Conclusion}

The correlation analysis was used to evaluate the results of the leaching experiments. The dissolved ions concentrations and $\mathrm{pH}$ values of leachates as well as the leached out concentrations of selected ions from the concrete samples of various compositions were investigated. It was found that the leaching of silicon do not depend on percentage of fly ash cement replacement. Similar findings can be concluded for aluminium and calcium in case of fly-ash-based concretes. Silicon hydroxide seems to be the main form of silicon to be leached out form all concrete samples regardless the fly ash content. Leaching in manganese shows inverse proportion in medium correlation of samples FA0-FA10. In general, no significant correlation was observed for the manganese leaching.

\section{Acknowledgement}

This research has been carried out within the Grant No. 2/0145/15 of the Slovak Grant Agency for Science.

\section{Bibliography}

[1] Adenot F. and Buil M., 1992. Modelling of the corrosion of the cement paste by deionized water, Cem. Concr. Res. 22, 259-272.

[2] Carde C. and Francois R., 1999. Modelling the loss of strength and porosity increase due to the leaching of cement pastes, Cem. Concr. Compos. 21, 181-188.

[3] Dodge, Y. 2003. The Oxford Dictionary of Statistical Terms, OUP Oxford.

[4] Estokova, A., Ondrejka Harbulakova, V., Luptakova, A., Stevulova, N., Palascakova, L., Repka, M. 2013. Analysis of the selected characteristics changes of cement composites exposed to the sulphate environment, Chemical Engineering Transactions. Vol. 32, 1597-1602.

[5] Hitomi T., available at: http://www.spring8.or.jp/pdf/en/res_fro/05/131-132.pdf [access: 28 April 2015].

[6] Ikeda M. et al., 2004. Influence of type of cement on Ca leaching from concrete using experimental acceleration method, 29th conference on our world in concrete and structures, 25-26 august, Singapore.

[7] Kamali S. et al., 2003. Modelling the leaching kinetics of cement based materials influence of materials and environment, Cem. Concr. Compos.25, 451-458.

[8] Kosmatka H. et al., 2003. Design and Control of Concrete Mixtures, $14^{\text {th }}$ ed., Engineering Bulletin 001, PCA, USA.

[9] Kreyszig, E. 2011. Advanced Engineering Mathematics, John Wiley and sons, $10^{\text {th }}$ edition, 2011.

[10] Lamond J. F. and Pielert J. H., 2006. Significance of tests and properties of concrete and concrete-making materials, ASTM International, New York.

[11] Mainguy M. et al., 2000. Modelling of leaching in pure cement paste and mortar, Cem. Concr. Res. 30, 83-90. 
[12] Moranville M. et al., 2004. Physicochemical equilibria of cement-based materials in aggressive environments - experiment and modeling, Cem. Concr.Res. 34, 1569-1578.

[13] Ondrejka Harbulakova, V., Purcz, P., Estokova, A., Luptakova, A., Repka, M. 2015. Using a Statistical Method for the Concrete Deterioration Assessment in Sulphate Environment, Chemical Engineering Transaction, Vol.43.

[14] Ondrejka Harbulakova, V., Luptakova, A., Estokova, A., Stevulova, N., Palascakova, L. 2012. A Using of Coal Fly Ash in Concrete Materials and the Durability of Materials Testing Considering the Resource Optimization, Visions for the Future of Housing : Mega Cities : proceedings of the 38th IAHS World Congress: Istanbul, Turkey, April 16-19, Technical University, 959-964.

[15] Rozière, E. et al., 2009. Durability of concrete exposed to leaching and external sulphate attacks Cem. Concr. Res 39, 1188-1198.

[16] SCA, 2002. Slag cement in concrete, no. 11, Slag Cement association available at: http://www.slagcement.org/pdf/no11\%20Slag\%20Cement\%20and\%20Fly\%20Ash. pdf [access: 28 April 2015].

\section{BADANIE ZALEŻŃOŚCI POMIĘDZY WYMYWANIEM BETONU ORAZ PH Z ZASTOSOWANIEM STATYSTYCZNEGO PODEJŚCIA}

Streszczenie

Woda wywiera negatywny wpływ biorąc udział w procesie degradacji cementu oraz zmienia wodę porową betonu, jak i skład fazy stałej. Wymywanie produktów cementowych wykazało podobne właściwości otrzymane za pomocą testów ługowania z uwzględnieniem $\mathrm{pH}$. W pracy skoncentrowano się na badaniach odcieku z próbek betonu o różnym $\mathrm{pH}$ oraz jonów $\mathrm{Si}, \mathrm{Ca}, \mathrm{Al}, \mathrm{Fe}$ i Mn wypłukanych z matrycy cementowej, które były wyznaczane po każdym z pięciu cykli eksperymentalnych. Badaniu poddano trzy zestawy próbek bez zawartości popiołu lotnego i zawierającego popiół lotny jako zamiennik cementu (odpowiednio 5\% wag. do 10\% wag.,). Metody statystyczne były wykorzystywane do oceny intensywności oraz czasu uszkodzeń w zależności od $\mathrm{Si} / \mathrm{pH}, \mathrm{Ca} / \mathrm{pH} \mathrm{Al} / \mathrm{pH}$ i $\mathrm{Fe} / \mathrm{pH}$ oraz $\mathrm{Mn} / \mathrm{pH}$ dla poszczególnych próbek. W pracy została również przedstawiona korelacja pomiędzy procesami wymywania w zależności od rodzaju betonu.

Słowa kluczowe: współczynnik korelacji, woda destylowana, wapń, krzem

DOI:10.7862/rb.2016.212

Przestano do redakcji: $17.06 .2016 r$.

Przyjęto do druku: 30.11.2016r. 